ORIGINAL ARTICLE

\title{
Benefits and harms of direct to consumer advertising: a systematic review
}

\section{S Gilbody, P Wilson, I Watt}

See end of article for authors' affiliations

......................

Correspondence to: Dr S Gilbody, Senior Lecturer in Mental Health Services Research, Department of Health Sciences, Seebohm Rowntree Building, Alcuin College, University of York YO10 5DD; sg519@york. ac.uk

Accepted for publication 18 April 2005
Background: Direct to consumer advertising is increasingly used by the pharmaceutical industry, but its benefits and harms have yet to be summarised in a comprehensive and rigorous manner.

Methods: A systematic review was conducted of robust evaluations of the impact (positive and negative) of direct to consumer advertising. A broad range of databases and data sources (including Cinahl, Embase, HMIC, HSRProj, Medline, Psyclnfo, and the internet) were searched from inception to 2004.

Results: From 2853 citations only four reports were found that met the strict inclusion criteria and provided usable results. Direct to consumer advertising is associated with increased prescription of advertised products and there is substantial impact on patients' request for specific drugs and physicians' confidence in prescribing. No additional benefits in terms of health outcomes were demonstrated.

Discussion: Direct to consumer advertising is banned in most countries, and the research evidence tends to support the negative impact that is feared by those who support a legislative ban. Further research is needed into the clinical and economic impact of direct to consumer advertising in healthcare systems.
$\mathrm{T}$ he promotion of prescription only medicines using direct to consumer advertising (DTCA) is increasingly used by the pharmaceutical industry as a means of enhancing market share, with more than US\$2.5 billion spent in 2001. ${ }^{12}$ For example, in 2000 Merck spent $\$ 160$ million on DTCA of its (now withdrawn ${ }^{3}$ ) COX-2 selective inhibitor rofecoxib (Vioxx) which amounted to \$35 million more than Pepsico spent on promoting Pepsi that year. ${ }^{4}$

Proponents of DTCA argue that advertisements are a legitimate form of patient information, and the benefits of advertisements targeted directly at patients and the public include increased health awareness; improved patient-doctor communication; improved concordance and, ultimately, improved health outcomes. ${ }^{5}$ Opponents of DTCA highlight the fact that advertisements are not unbiased sources of information but, instead, tend to be one sided product appraisals which produce unrealistic expectations of the benefits of medicines. The consequences of these advertisements are that increased and inappropriate demand for new and expensive drugs will be generated. Such enterprises might also distort and undermine local and national initiatives to increase the appropriate and efficient prescribing of drugs. Further, generating public demand for specific treatments and drugs is likely to change fundamentally the nature of the patient-doctor relationship; doctors may feel under pressure to prescribe inappropriate and costly drugs even when they feel this is not appropriate to both the patient and the healthcare system as a whole. ${ }^{2}$ DTCA therefore has the potential to influence the quality of patient care at every level-from the individual patient encounter to the implementation of national policies and the overall efficiency of healthcare systems. Each of these can be answered empirically using appropriate research methods.

DTCA is currently allowed only in the US and New Zealand, although there are moves to introduce a ban in New Zealand. ${ }^{6}$ The European Parliament has emphatically opposed DTCA in line with the "precautionary principle", protecting or denying European consumers depending on one's perspective. Despite this decision, DTCA is a topic that will not go away, especially as the internet has made national restrictions seem increasingly irrelevant.
There is a clear division between those who would support DTCA and those who oppose it. Ongoing debates relating to the role of DTCA, and whether legislation should remain or be changed, have hitherto been made on the basis of selective reporting of research evidence. To our knowledge, there has not been an attempt to produce a systematic overview of the research evidence into this topic. Systematic reviews have the potential to inform both patient care and health policy. In order to inform the debate on DTCA, we have conducted a systematic review of the clinical and economic impact of DTCA on patients and clinicians_-both positive and negative.

\section{METHODS}

We carried out our systematic review according to clear guidelines set down by the UK NHS Centre for Reviews, ${ }^{7}$ and our results are presented according to guidelines laid down in the QUOROM statement. ${ }^{8}$

\section{Search strategy}

We searched a wide range of biomedical, psychological, "grey" literature, and marketing databases (ABI Global, Cinahl, Embase, HMIC, HSRProj, Medline, PsycInfo, Sigle, Web of Science, Medline Plus and PreMedline, DARE, and NHS Economic Evaluation Database) from 1987 to October 2004. Free text search terms were created around the term "direct to consumer advertising" and associated synonyms. Medical subject headings (MeSHs) relating to consumer attitudes, patient education, consumer health information, drug information, advertising, and marketing were also exploded. The reference lists of included studies were scrutinised for further studies and keyword searches of the internet were also undertaken.

\section{Study inclusion criteria}

Studies were included that examined the impact of any form of mass media DTCA of prescription only medicines on the following outcomes:

Abbreviations: DTCA, direct to consumer advertising 
- health seeking behaviours of patients at the point of access to care;

- requests for prescription only medicines;

- patient-doctor communication and satisfaction with care;

- prescribing patterns;

- direct and indirect costs (including drug costs, healthcare and social costs).

Studies that only reported knowledge and awareness of advertising campaigns were excluded.

Mass media and population level interventions such as DTCA are rarely evaluated using randomised designs. However, in order to draw causal inference from studies examining population level interventions, it is important to use control groups or comparative historical time periods. ${ }^{9}$ For this reason, we decided to extend our inclusion criteria beyond the conventional randomised controlled trial. In line with guidelines suggested by the Cochrane Effective Practice and Organisation of Care (EPOC) group, ${ }^{10}$ the following study designs were included: randomised controlled trials, controlled clinical trials, controlled before-and-after studies, and interrupted time series analyses. We also included crosssectional surveys where they included a control or comparison group. We sought full economic evaluations based on the above epidemiological designs, combining cost and consequence. ${ }^{11}$

\section{Study selection}

The results of our literature searches were scrutinised independently by two researchers. References to studies which could potentially be included were ordered and scrutinised further. A flow diagram describing the inclusion and rejection of studies is shown in fig 1 .

\section{Data extraction, quality assessment, and research synthesis}

Data were independently extracted by two researchers. Data on study design, population, intervention, outcomes, results, and method of analysis were initially summarised in a tabular form. Study quality was assessed according to accepted criteria. $^{710}$

We anticipated that substantial heterogeneity in terms of study design, populations, and mode of DTCA might be found among the studies, making a formal statistical method of synthesis (meta-analysis) inappropriate. We therefore

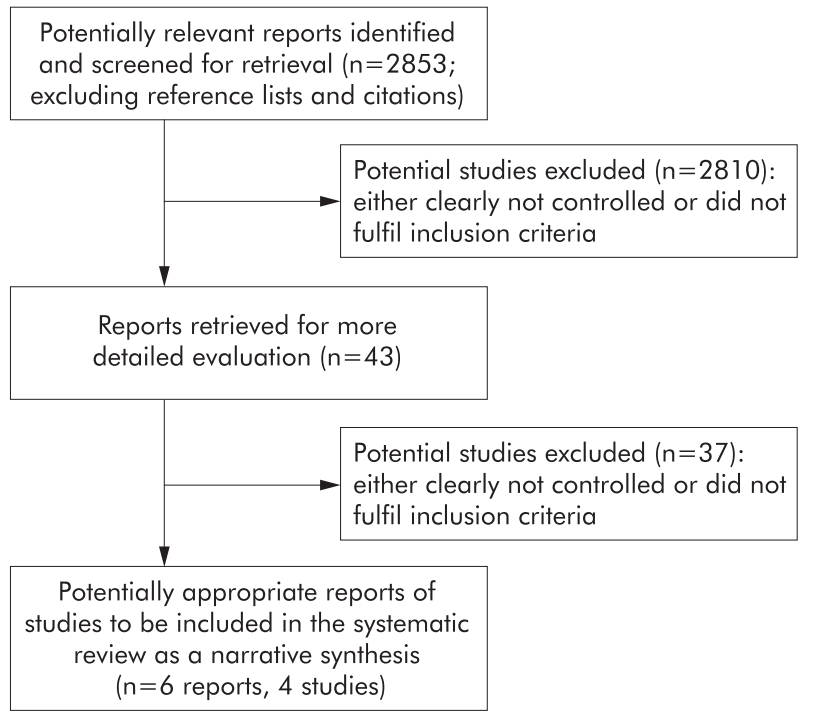

Figure 1 QUOROM study flow diagram. ${ }^{8}$ conducted a descriptive synthesis in line with accepted guidelines. $^{7}$ Salient design features and outcomes were considered, with due reference to the overall quality of the evaluation. For example, prospective controlled studies were considered superior to cross sectional studies, and interrupted time series were considered to be interpretable when several time points before and after the intervention or introduction of DTCA were presented.

\section{RESULTS}

Our searches identified 2853 publications from which only four studies ( six publications) met our strict inclusion criteria and provided usable data (table 1). Very few of the reports identified by our searches did, in fact, represent actual evaluations of the impact of DTCA. Of the studies that did not fulfil our strict inclusion criteria, many were reports of the impact of DTCA in increasing brand awareness in the form of population surveys and opinion polls-for example, the national survey of consumer reactions to direct to consumer advertising ${ }^{12}$ - these were not included as they were neither controlled nor did they examine actual behaviour or our specified healthcare outcomes. Of the studies that did directly examine the impact of DTCA in relation to health care, common reasons for exclusion were: the failure to use a control group in cross sectional studies ${ }^{13}$ or descriptions of spending on DTCA without reference to a specific drug or product or clinical context. ${ }^{14}$ Of the economic studies that were identified, none combined cost and consequence within the context of a robust epidemiological design, but either described drug costs alone or relied on economic modelling and econometric prediction. ${ }^{15}$

Of the four included studies, three were interrupted time series, comparing periods of time before and after the introduction of DTCA. ${ }^{16-18}$ Two interrupted time series studies conducted in the US found a significantly increased trend in the prescribing volume of drugs that had been the subject of DTCA campaigns. ${ }^{16}{ }^{17}$ The effect of DTCA seemed to both increase the number of new diagnoses of a condition and tended to increase the proportion of prescriptions specifically for the advertised drug. For example, Zachry et $a l^{17}$ found that advertising budgets for cholesterol lowering drugs increased year on year during the 1990s, and that every \$1000 spent advertising cholesterol lowering drugs was associated with approximately 32 extra people being diagnosed with hyperlipidaemia and 41 advertised cholesterol lowering drugs being prescribed. Similarly, Basara ${ }^{16}$ found that a specific campaign for a migraine treatment (sumatriptan) was associated with a marked increase in sales over the first month of a campaign $(\mathrm{p}<0.0006)$ which, if extrapolated across the US market, was associated with \$11.5 million in sales annually.

A European study ${ }^{18}$ examined the impact of a mass media campaign sponsored by a pharmaceutical company to increase awareness of and treatment for a fungal nail condition (onchomycosis). A ban on product specific DTCA prevented the company naming their product, but the overall "awareness campaign" was associated with both an increase in new prescriptions and the market share of the company's specific antifungal agent (increased prescribing volume during the period of the campaign from 6.50 prescriptions per 1000 person years (95\% CI 6.33 to 6.66 ) to 15.2 (95\% CI 13.5 to 16.9$)$ ).

A controlled study by Mintzes and colleagues ${ }^{19-21}$ examined the impact of DTCA in the US compared with Canada (where DTCA is banned, although cross border exposure to DTCA still exists) using a cross sectional survey of physicians and patients. Patients in the US were more likely to request DTCA drugs $(7.3 \%$ v $3.9 \%$, OR $2.2,95 \%$ CI 1.2 to 4.1$)$, and physicians in both settings were more likely to acquiesce to these 
Table 1 Comparative studies examining the impact of direct to consumer advertising which fulfilled inclusion criteria

\begin{tabular}{|c|c|c|c|c|c|}
\hline Study and design & Population/setting & Intervention & $\begin{array}{l}\text { Outcomes studied and } \\
\text { follow up }\end{array}$ & Results & Comments \\
\hline \multirow[t]{2}{*}{$\begin{array}{l}\text { Basara }^{16} \\
\text { Interrupted time series }\end{array}$} & US primary care & $\begin{array}{l}\text { DTCA initiated after } 1993 . \\
\text { "Brand name" product specific } \\
\text { print or television DTCA. } \\
\text { Targeted at "common conditions" } \\
\text { (excluding "cosmetic or lifestyle" } \\
\text { drugs) }\end{array}$ & $\begin{array}{l}\text { New prescription volume } \\
\text { (monthly aggregates) of drugs } \\
\text { subject to DTCA. Derived from } \\
\text { "physician level" prescribing } \\
\text { data }\end{array}$ & $\begin{array}{l}\text { DTCA resulted in increased } \\
\text { prescribing volume }\left(R^{2}=0.90,\right. \\
p<0.00001) \text {. } \\
\text { The sustained increase in } \\
\text { prescription volume was subject } \\
\text { to exponential decline as the } \\
\text { marketing campaign progressed }\end{array}$ & \multirow[t]{2}{*}{$\begin{array}{l}\text { Clustering of physician and } \\
\text { demographic characteristics } \\
\text { accounted for in design and } \\
\text { analysis }\end{array}$} \\
\hline & $\begin{array}{l}\text { Four representative } \\
\text { geographical areas } \\
\text { in the US }\end{array}$ & $\begin{array}{l}\text { Migraine treatment (sumatriptan) } \\
\text { chosen as an exemplar }\end{array}$ & $\begin{array}{l}\text { Six months data pre DTCA and } \\
11 \text { months post DTCA analysed }\end{array}$ & $\begin{array}{l}\text { Sales response decreased } \\
\text { exponentially following } \\
\text { termination of DTCA }\end{array}$ & \\
\hline \multirow[t]{4}{*}{$\begin{array}{l}\text { Mintzes et al }{ }^{19-21} \\
\text { Comparative cross } \\
\text { sectional study }\end{array}$} & Primary care & $\begin{array}{l}\text { DTCA of any type used in US } \\
(1999-2000)\end{array}$ & $\begin{array}{l}\text { Patients belief that they needed } \\
\text { medicine }\end{array}$ & $\begin{array}{l}\text { Patients believed that they } \\
\text { needed medication more often } \\
\text { in Sacramento than } \\
\text { in Vancouver (OR } 2.6 \text {, } \\
95 \% \mathrm{Cl} 1.5 \text { to } 4.3 \text { ). Specific } \\
\text { belief that this should } \\
\text { be a DTCA drug also } \\
\text { higher (OR } 1.4,95 \% \mathrm{Cl} 1.1 \\
\text { to } 1.8 \text { ). Most common request } \\
\text { for branded antihistamines }\end{array}$ & \multirow[t]{4}{*}{$\begin{array}{l}\text { Clustering and demographics } \\
\text { accounted for in design and } \\
\text { analysis }\end{array}$} \\
\hline & \multirow{3}{*}{$\begin{array}{l}\text { Patients and clinicians in } \\
\text { Sacramento (DTCA group } \\
\mathrm{N}=683 \text { patients and } 38 \\
\text { clinicians) and Vancouver } \\
\text { (control group } \mathrm{N}=748 \\
\text { patients and } 40 \\
\text { physicians) }\end{array}$} & & $\begin{array}{l}\text { Patients' requests for } \\
\text { prescriptions }\end{array}$ & $\begin{array}{l}\text { Patients requested specific DTCA } \\
\text { drugs more often in Sacramento } \\
\text { than in Vancouver }(7.3 \% \text { v } 3.2 \% \text {, } \\
\text { OR } 2.2,95 \% \mathrm{Cl} 1.2 \text { to } 4.1)\end{array}$ & \\
\hline & & & $\begin{array}{l}\text { Clinicians' prescriptions in } \\
\text { response to these requests }\end{array}$ & $\begin{array}{l}\text { Patients were more likely to } \\
\text { receive a prescription of a DTCA } \\
\text { drug than a non-DTCA drug (OR } \\
8.7,95 \% \mathrm{Cl} 5.4 \text { to 14.2); rate } \\
\text { similar in Sacramento and } \\
\text { Vancouver. Those who requested } \\
\text { a specific DTCA drug were more } \\
\text { likely to receive a new prescription } \\
\text { (for any drug) than those who did } \\
\text { not (OR 16.9, } 95 \% \mathrm{Cl} 7.5 \text { to } 38.2\end{array}$ & \\
\hline & & & $\begin{array}{l}\text { Clinicians' satisfaction with } \\
\text { prescribing decisions }\end{array}$ & $\begin{array}{l}\text { Clinicians more likely to express } \\
\text { dissatisfaction or ambivalence } \\
\text { with patient requested drugs (OR } \\
\text { for requested DTCA drugs } 7.1 \text { in } \\
\text { Sacramento }(95 \% \mathrm{Cl} 2.5 \text { to } 19.8 \text { ) } \\
14.5 \text { in Vancouver }(95 \% \mathrm{Cl} 2.6 \text { to } \\
\text { 81.4) }\end{array}$ & \\
\hline \multirow[t]{3}{*}{$\begin{array}{l}\text { 't Jong et } a l^{18} \\
\text { Interrupted time } \\
\text { series }\end{array}$} & $\begin{array}{l}\text { Netherlands primary } \\
\text { care }\end{array}$ & $\begin{array}{l}\text { DTCA mass media campaign } \\
\text { on onchomycosis (fungal nail } \\
\text { infection) by Novartis, a } \\
\text { manufacturer of terbinafine }\end{array}$ & $\begin{array}{l}\text { Prescription volume of } \\
\text { terbinafine (product of the } \\
\text { company } \\
\text { initiating the awareness } \\
\text { campaign) }\end{array}$ & $\begin{array}{l}\text { Prescription volume for } \\
\text { terbinafine increased during } \\
\text { the period of the campaign from } \\
6.50 \text { prescriptions per } 1000 \\
\text { person years }(95 \% \mathrm{Cl} 6.33 \text { to } \\
6.66) \text { to } 15.2(95 \% \mathrm{Cl} 13.5 \text { to } \\
\text { 16.9) }\end{array}$ & \multirow{3}{*}{$\begin{array}{l}\text { Scant methodological details } \\
\text { making it difficult to comment } \\
\text { on method of analysis. } \\
\text { However, several data points } \\
\text { available before and during } \\
\text { the campaign. }\end{array}$} \\
\hline & $\begin{array}{l}\text { Research database } \\
\text { containing prescription } \\
\text { information on } 150 \\
\text { practices ( } 470775 \\
\text { patients, } 1.5 \text { million }\end{array}$ & $\begin{array}{l}\text { Advertising campaign between } \\
2000-2001\end{array}$ & $\begin{array}{l}\text { Prescription volume of } \\
\text { itraconazole (generic drug also } \\
\text { available for treating } \\
\text { onchomycosis) }\end{array}$ & $\begin{array}{l}\text { Prescription volume of } \\
\text { itraconazole fell from } 6.84 \\
\text { prescriptions per } 1000 \text { person } \\
\text { years }(95 \% \mathrm{Cl} 6.67 \text { to } 7.01) \text { to } \\
6.07(95 \% \mathrm{Cl} 5.86 \text { to } 6.28)\end{array}$ & \\
\hline & $\begin{array}{l}\text { patient years) between } \\
1996 \text { and } 2002\end{array}$ & & $\begin{array}{l}\text { New consultation rate for } \\
\text { onchomycosis }\end{array}$ & $\begin{array}{l}\text { New consultation rate for } \\
\text { onchomycosis increased from } 5.9 \\
\text { per } 1000 \text { person years ( } 95 \% \mathrm{Cl} \\
5.6 \text { to } 6.2 \text { ) in } 1999 \text { to a peak of } \\
8.2(95 \% \mathrm{Cl} 7.9 \text { to } 8.6 \text { ) in } 2000-1 \\
\text { and fell to } 4.9(95 \% \mathrm{Cl} 4.6 \text { to } 5.1) \\
\text { per } 1000 \text { person years in } 2002\end{array}$ & \\
\hline \multirow[t]{3}{*}{$\begin{array}{l}\text { Zachry et al } \\
\text { Interrupted time } \\
\text { series }\end{array}$} & US primary care & $\begin{array}{l}\text { DTCA mass media campaigns for } \\
\text { five classes of prescription only } \\
\text { medicines (antihistamines, anti- } \\
\text { hypertensives, anti-ulcer drugs, } \\
\text { benign prostatic hypertrophy } \\
\text { ?(BPH) drugs, and cholesterol } \\
\text { lowering drugs) }\end{array}$ & $\begin{array}{l}\text { Monthly advertising expenditure } \\
\text { for named DTCA drugs }\end{array}$ & $\begin{array}{l}\text { A positive association }(\mathrm{p}<0.05) \\
\text { between advertising expenditure, } \\
\text { diagnosis and prescription } \\
\text { volume (by class and by named } \\
\text { drug) was found for } \\
\text { antihistamines, anti-ulcer drugs, } \\
\text { and cholesterol lowering drugs }\end{array}$ & \multirow{3}{*}{$\begin{array}{l}\text { Clustering and intercorrelation } \\
\text { of data points included in } \\
\text { analyses. Several data points } \\
\text { available before and during } \\
\text { the DTCA campaign }\end{array}$} \\
\hline & & & $\begin{array}{l}\text { New diagnoses for the } \\
\text { advertised drugs' FDA } \\
\text { approved indications }\end{array}$ & $\begin{array}{l}\text { Regression analysis showed that } \\
\text { every } \$ 1000 \text { spent advertising } \\
\text { cholesterol lowering drugs was }\end{array}$ & \\
\hline & $\begin{array}{l}\text { Research database } \\
\text { containing details of } \\
195577 \text { clinician } \\
\text { encounters from } 1992 \text { to } \\
1997 \text { correlated with an } \\
\text { advertising database } \\
\text { detailing all advertising } \\
\text { expenditure for named } \\
\text { drugs subject to direct to } \\
\text { consumer advertising } \\
\text { (including TV, radio, print } \\
\text { media) }\end{array}$ & $\begin{array}{l}\text { Advertising campaigns between } \\
1992 \text { and } 1997 \text {. Campaigns had } \\
\text { to last for a minimum of } \\
18 \text { months }\end{array}$ & $\begin{array}{l}\text { Prescription volume for drugs } \\
\text { belonging to the same class } \\
\text { Prescription volume for branded } \\
\text { drugs subject to DTCA } \\
\text { All outcomes pre-advertising } \\
\text { and for } 19 \text { months during the } \\
\text { advertising campaign }\end{array}$ & $\begin{array}{l}\text { associated with approximately } \\
32 \text { people diagnosed with } \\
\text { hyperlipidaemia and } 41 \\
\text { cholesterol lowering drug } \\
\text { prescriptions being written }\end{array}$ & \\
\hline
\end{tabular}


requests despite feeling ambivalent about the drug that was prescribed. Those who requested a specific DTCA drug were 16 times more likely to receive a drug than those who did not request a specific drug (OR 16.9, 95\% CI 7.5 to 38.2).

No studies were found that examined the impact of DTCA on patient satisfaction with care, or the impact of DTCA and altered prescribing on actual health outcomes. There were also no studies that examined the cost effectiveness of DTCA by combining health outcomes and the economic costs of altered prescribing.

\section{DISCUSSION}

To our knowledge, this is the first application of a systematic review method in this area of practice and policy. Given the importance of DTCA and discussion that has taken place in the medical and lay press, ${ }^{2522}{ }^{23}$ we were surprised that the impact of this policy has not been subject to more extensive or rigorous evaluation. From the limited research available, our main conclusion is that DTCA does alter prescribing behaviour and volume. This conclusion is based on three interrupted time series studies and one comparative cross sectional study. Our review also highlights the fact that no studies have examined the impact of direct to consumer advertising on either health outcomes or examined the costs and health and social consequences of DTCA. These conclusions are based on a systematic evaluation of the research literature rather than an unsystematic (and potentially biased) overview. ${ }^{24}$

Proponents of DTCA claim that advertisements are a legitimate source of quality patient information. ${ }^{5}$ Informing and empowering patients are major themes in the UK and in many healthcare systems, and a case for DTCA might be argued to help develop a more informed and assertive population. Arguments against DTCA principally centre on concerns about the pharmaceutical industry's ability to produce unbiased information. Given the nature of market economics, the primary aim of DTCA campaigns is to increase market share and profit rather than enhance well being. ${ }^{23}$ Hence, advertisements may not look at all treatment options including non-drug treatments, or provide a consumer with comprehensive information on potential adverse effects. Concerns about the quality of information in advertisements are in many cases justified, with one in four products violating the basic regulations set down by the Food and Drug Administration. ${ }^{22}$

Hoffman and Wilkes, ${ }^{25}$ reflecting on the experience in the US, assert that DTCA "unreasonably increases consumer expectations, forces doctors to spend time disabusing patients of misinformation, diminishes the doctor-patient relationship because a doctor refuses to prescribe an advertised drug, or results in poor practice if the doctor capitulates and prescribes an inappropriate agent."

The research presented in this review tends to support this assertion. No empirical research has demonstrated better communication and improved health outcomes. Given the lack of evidence of a beneficial effect on healthcare quality, concerns that DTCA undermines efforts to improve efficiency and cost-conscious prescribing-including use of generic drugs where branded drugs confer marginal benefit-appear well founded.

The results of the study conducted in the Netherlands also raises questions about the effects of industry funded disease awareness campaigns. ${ }^{18}$ The limited evidence available seems to suggest that such campaigns can increase market share and product awareness. Similarly, it does seem to create markets which did not previously exist by generating demand for treatments for non life-threatening conditions about which the public has little awareness_-such as fungal nail infections, social anxiety disorder, ${ }^{26}$ or female sexual dysfunction. ${ }^{27}$ From the perspective of the pharmaceutical

\section{Key messages}

- Direct to consumer advertising (DTCA) is currently allowed only in the US and New Zealand.

- Proponents suggest DTCA is a legitimate form of patient education with the potential for more informed patients and better health care.

- Opponents question the wisdom of DTCA, since it potentially distorts the patient-doctor relationship, rational health policies and prescribing practice, and generates demand without necessarily improving health outcomes.

- A systematic review of evidence of the clinical and economic consequences confirms that DTCA does influence patient demand and doctor prescribing behaviour. No evidence of health benefit was found since this had not been examined in any detail.

- Calls to allow DTCA should be resisted in the absence of any evidence of benefit from such an influence of prescribing behaviour.

industry, disease awareness campaigns may offer an alternative promotional approach in regions where DTCA is currently prohibited. However, from the perspective of healthcare systems and governments struggling to contain ever increasing drug budgets, campaigns to increase awareness of non-life threatening conditions could generate demand for treatments which will ultimately divert time and resources away from other more important conditions. ${ }^{26}{ }^{28}$ This is a topic where further research is clearly justified.

Since DTCA is currently banned in most parts of the world, legislators and policy makers will periodically revisit the issue of whether DTCA should be allowed. Similarly, there is a powerful lobby on the part of the pharmaceutical industry to allow DTCA. The main finding of this review is the identification of a void in terms of the evidence of the wider impact of DTCA - over and above increased prescriptions and market share. Policy making must therefore proceed in the absence of a definitive answer as to the specific consequences of DTCA on individual patient care and healthcare systems. The onus is on those who might support DTCA to produce evidence of benefit and, in the absence of this evidence, we must assume that the likely disbenefits (clinical and economic) outweigh the as yet unproven benefits. This opinion was reflected by Mintzes and colleagues ${ }^{19}$ when they examined this issue for the benefit of the Canadian healthcare system. They concluded that: "We could find no evidence of improved drug utilization, improved doctor/patient relations, or reductions in hospitalization rates, serious morbidity or mortality attributable to DTCA. The aim of the prohibition of prescription drug advertising in Canada is health protection. Any legislative change that would weaken the current restrictions on such advertising should be based on strong evidence that concerns about potential harm are unfounded, and-ideally-evidence of health benefits. On the contrary, we found a considerable body of evidence suggesting that such concerns are warranted, and no evidence that DTCA is likely to improve the health."

These are also the conclusions that can be drawn from the first systematic empirical overview of this topic.

Authors' affiliations

S Gilbody, I Watt, Department of Health Sciences, University of York, York YO10 5DD, UK 
P Wilson, NHS Centre for Reviews and Dissemination, University of York, York YO10 5DD, UK

\section{REFERENCES}

1 General Accounting Office. Prescription drugs. FDA oversight of direct-toconsumer advertising has limitations, Report to Congressional Requesters GAO-03-177. Washington, DC: United States General Accounting Office, 2002.

2 Mintzes B. For and against. Direct to consumer advertising is medicalising normal human experience: for. BMJ 2002;324:908-9.

3 Josefson D. Drug advertisers face scrutiny after potentially breaking FDA rules. BMJ 2002;325:1262.

4 National Institute of Health Care Management. Prescription drugs and mass media advertising 2000. Washington, DC: NIHCM Foundation, 2001.

5 Bonaccorso SN, Sturchio JL. For and against. Direct to consumer advertising is medicalising normal human experience: against. BMJ 2002;324:910-1.

6 Burton B. Drug industry to fight New Zealand's move to ban direct to consumer advertising. BMJ 2004;328:1036.

7 NHS Centre for Reviews and Dissemination. Undertaking systematic reviews of research on effectiveness, CRD Report 4 (2nd edition). York: University of York, 2001

8 Moher D, Cook DJ, Eastwood S, et al. Improving the quality of reports of metaanalyses of randomised controlled trials: the QUOROM statement. Lancet 1999;354:1896-8.

9 Cook TD, Campell DT. Quasi-experimentation: design and analysis issues for field settings. Boston: Houghton Mifflin, 1979.

10 Bero L, Grilli R, Grimshaw J, et al. The Cochrane Effective Practice and Organisation of Care Group (EPOC) module. The Cochrane Library. Issue 4. Oxford: Update Software, 1998.

11 NHS Centre for Reviews and Dissemination. Making cost effectiveness information available: the NHS Economic Evaluation Database project. CRD Report 6. York: University of York, 1996.

12 Anon. National survey of consumer reactions to direct to consumer advertising. Prevention Magazine 1999.

13 Weissman JS, Blumenthal D, Silk AJ, et al. Physicians report on patient encounters involving direct-to-consumer advertising. Health Aff (Millwood) January-June 2004 (Supplement web exclusives, W4-219-33).
14 Rosenthal MB, Berndt ER, Frank RG, et al. Promotion of prescription drugs to consumers. N Engl J Med 2002;346:498-505.

15 Wosinska M. Just what the patient ordered? Direct to consumer advertising and the demand for pharmaceutical products. Harvard Business School Marketing Research Papers Nos 02-04, 2002.

16 Basara LR. The impact of a direct-to-consumer prescription medication advertising campaign on new prescription volume. Drug Inf J 1996;30:715-29.

17 Zachry WMr, Shepherd MD, Hinich MJ, et al. Relationship between direct-toconsumer advertising and physician diagnosing and prescribing. Am J Health Syst Pharm 2002;59:42-9.

18 't Jong GW, Stricker BHC, Sturkenboom MCJM. Marketing in the lay media and prescriptions of terbinafine in primary care: Dutch cohort study. BMJ 2004;328:931.

19 Mintzes B, Barer ML, Bassett K, et al. An assessment of the health system impacts of direct-to-consumer advertising of prescription medicines (DTCA). Volume III: Patient information on medicines comparative patient/doctor survey in Vancouver and Sacramento. Vancouver: University of British Columbia Health Policy Research Unit, 2001.

20 Mintzes B, Barer ML, Kravitz RL, et al. Influence of direct to consumer pharmaceutical advertising and patients' requests on prescribing decisions: two site cross sectional survey. BMJ 2002;324:278-9.

21 Mintzes B, Barer ML, Kravitz RL, et al. How does direct-to-consumer advertising (DTCA) affect prescribing? A survey in primary care environments with and without legal DTCA. Can Med Assoc J 2003;169:405-12.

22 Aitken M, Holt F. A prescription for direct drug marketing. McKinsey Quarterly 2000:82.

23 Wolfe SM. Direct-to-consumer advertising-education or emotion promotion? N Engl J Med 2002;346:524-6.

24 Mulrow CD, Cook D, eds. Systematic reviews: synthesis of best evidence for healthcare decisions. Philadelphia: American College of Physicians, 1998.

25 Hoffman JR, Wilkes M. Direct to consumer advertising of prescription drugs. BMJ 1999:318:1301-2.

26 Moynihan R, Heath I, Henry D, et al. Selling sickness: the pharmaceutical industry and disease mongering. BMJ 2002;324:886-91.

27 Moynihan R. The marketing of a disease: female sexual dysfunction. BMJ 2005;330:192-4.

28 Quick JD, Hogerzheil HV, Rago L, et al. Ensuring ethical drug promotionwhose responsibility? Lancet 2003;362:427. 